\title{
Structural characteristics and herd management practices of dairy cattle farms registered to pre-herdbook and herdbook systems
}

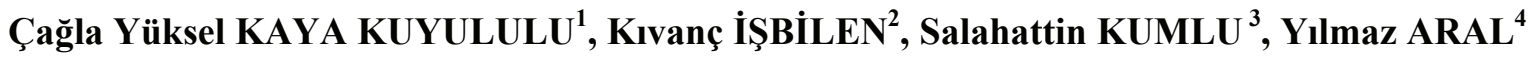 \\ ${ }^{1}$ Frankfurt School of Finance and Management IAS, Ankara; ${ }^{2}$ Cattle Breeders' Association of Aydın, Aydın; ${ }^{3}$ Department of Animal \\ Science, Faculty of Agriculture, Akdeniz University, Antalya; ${ }^{4}$ Department of Animal Health Economics and Management, Faculty \\ of Veterinary Medicine, Ankara University, Ankara.
}

\begin{abstract}
Summary: This research is based on the findings of survey study carried out vis-à-vis with 501 randomly sampled dairy cattle breeders in 15 districts of Aydın. Results show that $11 \%$ of surveyed farms are registered to Preherdbook, $89 \%$ to Herdbook of Cattle Breeders' Association of Aydin (CBAA) and weighted average of herd size is calculated as 23 heads of heifer (>1 year old). In $87 \%$ of cases main source of income is declared as milk production and $95 \%$ of breeders are male, $51 \%$ is between $31-49$ years old. Of all breeders $78 \%$ graduated from primary school and $92 \%$ of all farms use family labor while $11 \%$ hires labor. $97 \%$ has milking machine, $48 \%$ measure their milk with milk buckets and $85 \%$ of breeders declared keeping Herdbook records, whereas $7 \%$ of all are bookkeeping. The housing in $74 \%$ of farms is roofed-open, loose/free-stall while $16 \%$ has enclosed, tied-stall system. $4.5 \%$ has individual calf pens, $30.6 \%$ has group pens and rest keeps the calves with adults. Veterinary services are received upon request (39\%), mostly for Artificial Insemination (AI), treatment and calving difficulty. Breeders change feed ration during dry-period in $80.4 \%$, don't change in $20 \%$. Results show that breeders in Aydın need to receive more information and advisory services on herd management practices, in particular feeding, herd health and farm economics.
\end{abstract}

Key words: Aydın, dairy cattle, farm structure, herd management.

\section{Önsoyküğütü ve soykütüğü’ne kayıtlı süt sığırcılığı işletmelerinin yapısal özellikleri ve sürü yönetimi uygulamaları}

Özet: Bu araştırmada, Aydın Damızlık Sığır Yetiştiricileri Birliği’ne (ADSYB) kayıtlı işletmelerin ve yetiştiricilerin genel özellikleri ile yetiştiricilerin sürü yönetimi konusundaki bilgi seviyeleri incelenmiştir. Araştırma Aydın iline bağlı 15 ilçede, rastgele örnekleme yöntemiyle seçilmiş, farklı büyüklükte sürüye sahip 501 yetiştirici ile gerçekleştirilen yüz yüze anketlerden elde edilen bulgulara dayanmaktadır. Ankete konu olan işletmelerin sürü büyüklüğü ortalama 23 baş dişi sığırdır (> 1 yaş). Anketin yapıldığ1 işletmelerin \%87'sinde süt üretimi ana gelir kaynağı olarak bildirilmiştir. Yetiştiricilerin \%95'i erkek, \%51'i 31-49 yaş aralığındadır ve eğitim seviyeleri çoğunlukla ilkokul düzeyindedir (\%78). İşletmelerin \%92'sinde aile işgücü kullanılmaktadır. İşletmelerin \%97'sinde sağım makinesi, \%48'inde süt ölçüm kovası bulunmakta, \%85'inde soykütüğü verileri tutulurken, toplamın \%7'sinde muhasebe kayıtları tutulmaktadır. Ankete dahil işletmelerde $\% 74$ oranında yarı açık, serbest/serbest duraklı, \%16 oranında ise kapalı, bağlı, duraklı ahırların kullanıldığı tespit edilmiştir. Buzağılar için işletmelerin sadece \%4,5'inde ayrı bölme bulunmakta, \%30,6'sında buzağılar grup bölmelerinde, geri kalanında yetişkinlerle aynı ahırda tutulmaktadır. Veteriner hekimler işletmeye \%39 oranında ihtiyaç halinde ve çoğunlukla suni tohumlama, tedavi ve zor doğum için çağrılmaktadır. İşletmelerin \%80,4'ü kuru dönemde yem rasyonunu değiştirirken, \%20'sinin değiştirmediği bildirilmiştir. Sonuç itibariyle, Aydın ilinde yetiştiricilerin sürü yönetimi uygulamaları kapsamında özellikle yemleme, sürü sağlığı ve işletme ekonomisi alanında daha fazla bilgilendirmeye ve danışmanlık hizmetine ihtiyacı olduğu tespit edilmiştir.

Anahtar sözcükler: Aydın, süt sığırı, işletme yapısı, sürü yönetimi.

\section{Introduction}

Turkey has a significant amount of milk production and is ranked $10^{\text {th }}$ in the world (4). However, milk production per capita (174 kg/year) (2) is still lower than the level of developed countries such as EU (295 $\mathrm{kg} /$ year/capita) $(5,6)$ and USA $(280 \mathrm{~kg} /$ year/capita) $(7$, 8 ), and Turkey is ranking $31^{\text {st }}$ in the world with respect to per capita milk production (4) as of 2009.
Efficiency of milk production and cattle breeding is related with a good herd management and consistent breeding activities $(9,14,16,18,20,25)$. Milking of cows is the most important activity in the farm particularly in terms of profitability because it is directly linked with the well-being of the cows $(10,11)$. Young stock rearing is an important part of dairy farming. The first few months in a calf's life have utmost importance 
(12). There has been an ambitious effort for establishing a herdbook system, improving the breeding activities and herd management in dairy cattle farms in Turkey since 1995. Cattle Breeders' Associations (CBA) in provinces and their umbrella organization plays an important role in achieving this mission. Therefore, cattle breeders registered in the herdbook system could be expected to be more aware of and practicing herd management and breeding activities. Most of the main findings of previous studies carried out in CBAs' member farms show that the level of information on herd management is still limited (22, 23, 24). Nevertheless, there are other studies showing that herd management practices of member breeders are better compared to non-members (19) and, they are progressing (17).

Aydin is located in the main milk production area, Aegean, and Aydin solely represents 3\% of Turkey's milk production (375 thousand tons), 3\% of total cattle population (311 thousand heads) (2), 4\% of Herdbook farms (5323 farms) and 4\% of Herdbook cattle (173 thousand heads) (3) as of 2011. The average herd size of Herdbook farms in Aydin is 18 heads heifers per herd (heifers $>1$ year old), similar to herd size average of all Herdbook farms (17 heads heifers) in Turkey. The distribution of herds among different herd size classes show that nearly half (43.3\%) of Aydin's Herdbook farms are in 10-19 head herd size class (3).

This research was performed to determine the current structural characteristics and herd management practices of dairy cattle enterprises operating in Aydin province of Turkey.

\section{Materials and Methods}

The research material are the basic data retrieved from the E-Improvement System and survey results carried out at 501 dairy cattle farms located in Aydin province in 2011, and registered to either pre-herdbook (56 farms, 11\%) or Herdbook (445 farms, 89\%) system. The sample farms were randomly selected from a list of provincial Herdbook farms and, Pre-Herdbook farms with more than 5 cows. The survey questionnaire consisted of 63 questions, which intended to assess the demographics, herd, farm and labor structure, breeding activities, managerial skills and sources of information, thus revealing the information and advisory needs of dairy cattle breeders in Aydin. Survey study was carried out vis-à-vis with dairy cattle breeders. The coefficients introduced by Açıl and Demirci (1) were used for calculation of the labor used for cattle breeding and milk production activities in the surveyed farms. The survey results were analyzed with Excel, SPSS and JMP Statistics Programs, for calculation of frequencies, percentages and data clustering in order to obtain descriptive statistics.

\section{Results}

The first findings of the research focused on the differences of basic herdbook data between the population and surveyed farms focusing on the average herd size, lactation duration and milk yields (Table 1).

Table 1. Basic indicators of population and sample herds in herdbook system in Aydın (July, 2011)

Tablo 1. Aydın'da soykütüğüne kayıtlı populasyon ve örnek seçilen sürülere ilişkin temel göstergeler (Temmuz, 2011)

\begin{tabular}{lcc}
\hline Herdbook Herds & Population & Sample \\
\hline (Weighted) Average number of & 23 & 24 \\
heifers > 1 year old (heads) & 359 & 357 \\
Lactation Duration (days) & 6562 & 6507 \\
Milk Yield (lt) & 5546 & 5530 \\
$\begin{array}{l}\text { Milk Yield } \\
\text { (corrected for 305 days) (lt) }\end{array}$ & \\
\hline
\end{tabular}

With regards the main income source of the farms, $87 \%$ of breeders answered that milk production is their main source of income, while cattle breeding (sale of breeding cattle) and crop production were the main sources of income in $4 \%$ of the farms, separately, according to the survey results.

Demographics of breeders: Breeders of the surveyed farms are mostly men (95.2\%). Young (18-30) and old (over 65 years old) breeders have nearly the same percentage in the total population (Table 2).

If gender, age group and educational background are compared at the same time, it is seen that the majority of the breeders are primary school graduate men of 31-49 age group (36.0\%) (Table 3 ).

Herd size and breeds: Nearly half of the sample herds are in 10-19 head herd size class (43.3\%) while only $5.4 \%$ have more than 50 heads of heifers $(>1$ year old) (Table 4).

There are seven different breeds of dairy cattle in Aydin whereas Holstein and their crossbreds are the dominant breed ( $97 \%$ of farms). There are only cattle of the same breed in 358 farms $(71.5 \%)$ whereas 116 of the

Table 2. Age group and gender distribution of the surveyed breeders Tablo 2. Ankete dahil olan yetiştiricilerin yaş ve cinsiyet gruplarına dağılımı

\begin{tabular}{lccccccc}
\hline Breeders & $\begin{array}{c}18-30 \text { years } \\
\text { old, } \%\end{array}$ & $\begin{array}{c}31-49 \text { years } \\
\text { old, } \%\end{array}$ & $\begin{array}{c}50-65 \text { years } \\
\text { old, } \%\end{array}$ & $\begin{array}{c}\text { Over } 65 \text { years } \\
\text { old, } \%\end{array}$ & Total, $\%$ & $\begin{array}{c}\text { Total number of } \\
\text { breeders }\end{array}$ & $\begin{array}{c}\text { Total ratio of } \\
\text { breeders, } \%\end{array}$ \\
\hline Man & 5.5 & 51.4 & 37.9 & 5.2 & 100.0 & 477 & 95.2 \\
Woman & 4.1 & 66.7 & 29.2 & 0.0 & 100.0 & 24 & 4.8 \\
Total & 5.4 & 52.1 & 37.5 & 5.0 & 100.0 & 501 & 100 \\
\hline
\end{tabular}


farms $(23.2 \%)$ have cattle of two different breeds. 26 of the farms $(5.2 \%)$ have 3 different breeds in the farm.

Labor structure: To understand the labor structure of the dairy cattle farms in Aydın, breeders were asked about the family and hired labor, used for milk production and cattle breeding. More than half of the farms have two or more family members working for the milk production and cattle breeding. Hired labor is not very common since only 53 farms out of 501 (11\%) hired one (40 farms) or more (13 farms) workers to take care of the cattle, whereas 15 of the farms use both family and hired labor (Table 5).

Table 3. Distribution of breeders by their level of education, gender and age group

Tablo 3. Yetiştiricilerin eğitim seviyesi, cinsiyet ve yaş gruplarına dağılımı

\begin{tabular}{|c|c|c|c|c|c|c|c|}
\hline \multirow[b]{3}{*}{ Gender } & \multirow[b]{3}{*}{ Age Group } & \multicolumn{6}{|c|}{ Level of Education } \\
\hline & & \multicolumn{2}{|c|}{ Primary } & \multicolumn{2}{|c|}{ Elementary } & \multicolumn{2}{|c|}{ High School or Higher } \\
\hline & & $\begin{array}{c}\text { Total share, } \\
\%\end{array}$ & $\begin{array}{l}\text { Share in } \\
\text { gender, \% }\end{array}$ & $\begin{array}{c}\text { Total share, } \\
\%\end{array}$ & $\begin{array}{l}\text { Share in } \\
\text { gender, \% }\end{array}$ & $\begin{array}{c}\text { Total share, } \\
\%\end{array}$ & $\begin{array}{l}\text { Share in } \\
\text { gender, \% }\end{array}$ \\
\hline \multirow{5}{*}{ Men } & $18-30$ & 2.2 & 2.3 & 1.6 & 1.7 & 1.0 & 1.1 \\
\hline & $31-49$ & 36.0 & 37.8 & 5.1 & 5.3 & 8.1 & 8.5 \\
\hline & $50-65$ & 30.8 & 32.3 & 1.8 & 1.9 & 3.6 & 3.8 \\
\hline & $\geq 65$ & 5.0 & 5.3 & 0.0 & 0.0 & 0.0 & 0.0 \\
\hline & Sub-total & 74.0 & 77.7 & 8.5 & 8.9 & 12.7 & 13.4 \\
\hline \multirow{5}{*}{ Woman } & $18-30$ & 0.2 & 4.1 & 0.0 & 0.0 & 0.0 & 0.0 \\
\hline & $31-49$ & 2.6 & 54.1 & 0.2 & 4.2 & 0.4 & 8.3 \\
\hline & $50-65$ & 1.2 & 25.0 & 0.2 & 4.2 & 0.0 & 0.0 \\
\hline & $\geq 65$ & 0.0 & 0.0 & 0.0 & 0.0 & 0.0 & 0.0 \\
\hline & Sub-total & 4.0 & 83.2 & 0.4 & 8.4 & 0.4 & 8.4 \\
\hline \multicolumn{2}{|l|}{ TOTAL } & 78.0 & - & 8.9 & - & 13.1 & - \\
\hline \multicolumn{2}{|c|}{ Total number of respondents } & \multicolumn{2}{|c|}{388} & \multicolumn{2}{|c|}{44} & \multicolumn{2}{|c|}{65} \\
\hline
\end{tabular}

Table 4. Distribution of sample farms by herd size classes (head heifers)

Tablo 4. Örneklemdeki işletmelerin sürü büyüklüğü sınıflarına dağılımı (baş dişi sığır)

\begin{tabular}{lc}
\hline Herd size (head heifers/herd) & Sample, $\%$ \\
\hline$<3$ & $1.0 \%$ \\
$3-9$ & $22.0 \%$ \\
$10-19$ & $43.3 \%$ \\
$20-49$ & $28.3 \%$ \\
$50-99$ & $4.0 \%$ \\
$>=100$ & $1.4 \%$ \\
Total & $100 \%$ \\
Total number of farms & 501 \\
\hline
\end{tabular}

Table 5. Labor Force Unit (LFU) of family and hired labor for milk production and cattle breeding by herd size (head heifers) Tablo 5. Sürü büyüklügüne (dişi sığır) göre süt üretimi ve sığır yetiştiriciliği için kullanılan aile ve istihdam edilen Erkek İşgücü Birimi (EİB)

\begin{tabular}{|c|c|c|c|c|c|c|c|c|c|}
\hline \multirow{2}{*}{ Total N, \% } & & \multicolumn{6}{|c|}{ Herd Size Class (head heifers) } & \multicolumn{2}{|c|}{ TOTAL } \\
\hline & & $<3$ & $3-9$ & $10-19$ & $20-49$ & $50-99$ & $>=100$ & Total, $\%$ & Number of farms \\
\hline \multirow{5}{*}{$\begin{array}{l}\text { Labour } \\
\text { (LFU, family) }\end{array}$} & 0 & $0.0 \%$ & $1.4 \%$ & $2.8 \%$ & $3.8 \%$ & $2.2 \%$ & $1.0 \%$ & $11.2 \%$ & 56 \\
\hline & $<=1$ & $0.8 \%$ & $7.4 \%$ & $13.0 \%$ & $9.2 \%$ & $0.4 \%$ & $0.2 \%$ & $30.9 \%$ & 155 \\
\hline & $1-1.5$ & $0.2 \%$ & $4.4 \%$ & $10.4 \%$ & $2.4 \%$ & $0.6 \%$ & $0.0 \%$ & $18.0 \%$ & 90 \\
\hline & $>1.5$ & $0.0 \%$ & $8.8 \%$ & $17.2 \%$ & $13.0 \%$ & $0.8 \%$ & $0.2 \%$ & $39.9 \%$ & 200 \\
\hline & Total & $1.0 \%$ & $22.0 \%$ & $43.3 \%$ & $28.3 \%$ & $4.0 \%$ & $1.4 \%$ & $100.0 \%$ & 501 \\
\hline \multirow{5}{*}{$\begin{array}{l}\text { Labour } \\
\text { (LFU, hired) }\end{array}$} & 0 & $1.0 \%$ & $21.8 \%$ & $41.5 \%$ & $23.8 \%$ & $1.4 \%$ & $0.0 \%$ & $89.4 \%$ & 448 \\
\hline & $<=1$ & $0.0 \%$ & $0.2 \%$ & $1.4 \%$ & $3.8 \%$ & $2.0 \%$ & $0.6 \%$ & $8.0 \%$ & 40 \\
\hline & $1-1.5$ & $0.0 \%$ & $0.0 \%$ & $0.2 \%$ & $0.0 \%$ & $0.0 \%$ & $0.2 \%$ & $0.4 \%$ & 2 \\
\hline & $>1.5$ & $0.0 \%$ & $0.0 \%$ & $0.2 \%$ & $0.8 \%$ & $0.6 \%$ & $0.6 \%$ & $2.2 \%$ & 11 \\
\hline & Total & $1.0 \%$ & $22.0 \%$ & $43.3 \%$ & $28.3 \%$ & $4.0 \%$ & $1.4 \%$ & $100.0 \%$ & 501 \\
\hline
\end{tabular}


Table 6. Distribution of different housing systems in the surveyed farms by herd size (head heifers) Tablo 6. Anket kapsamındaki işletmelerde bulunan farklı barınak çeşitlerinin farklı sürü büyüklüklerine (baş dişi sığır) dağılımı

\begin{tabular}{ccccc}
\hline $\begin{array}{c}\text { Herd Size Class } \\
\text { (head heifers) }\end{array}$ & $\begin{array}{c}\text { Roofed-open, loose/free-stall } \\
\text { housing system }\end{array}$ & $\begin{array}{c}\text { Barn type for milking cows } \\
\text { Roofed-open, tied-stall } \\
\text { housing system }\end{array}$ & $\begin{array}{c}\text { Enclosed, tied-stall } \\
\text { housing system }\end{array}$ & $\begin{array}{c}\text { Enclosed, free-stall } \\
\text { housing system }\end{array}$ \\
\hline$<3$ & $0,8 \%$ & $0,0 \%$ & $0,2 \%$ & $0,0 \%$ \\
$3-9$ & $13,8 \%$ & $1,6 \%$ & $6,2 \%$ & $0,2 \%$ \\
$10-19$ & $30,6 \%$ & $5,8 \%$ & $6,4 \%$ & $0,6 \%$ \\
$20-49$ & $23,6 \%$ & $1,4 \%$ & $2,8 \%$ & $0,6 \%$ \\
$50-99$ & $3,6 \%$ & $0,0 \%$ & $0,4 \%$ & $0,0 \%$ \\
$>=100$ & $1,4 \%$ & $0,0 \%$ & $0,0 \%$ & $0,0 \%$ \\
Total & $73,8 \%$ & $8,8 \%$ & $16,0 \%$ & $1,4 \%$ \\
\hline
\end{tabular}

Land size: The size of the arable land used for agricultural production by the surveyed farms varies among different size classes. However, there are a small number of farms $(4.8 \%)$ which do not own or use any arable land for crop production or grazing of the livestock. When it comes to the land ownership, the survey results show that $77 \%$ of the farms in the sampled population own some amount of arable land. The breeders, who have responded as not being the owner of the land, use the land owned by their parents in more than one third of the cases. Surveyed cattle farms in Aydin have an average Utilized Agricultural Area of 27 da.

Record keeping: In order to understand the managerial skills of the breeders, the record keeping habits were questioned, and a significant number of breeders $(96 \%)$ declared that they were keeping records on their own; in which $95 \%$ of them keep these records on a notebook. The main data kept at farm level are the Herdbook (85\%) and insemination (84\%) data, whereas only $7 \%$ of the farms declared that, they also keep accounting data. A milking bucket which is used for measuring the amount of milk produced per cow which is necessary for Herdbook records, is present in half of the farms $(48 \%)$.

Housing systems: The housing of dairy cattle in Aydın region could be grouped as enclosed or roofedopen; loose, free or tied stall housing systems. Even though the use of different groups could vary according to the region, tradition and climate the survey results show that more than $70 \%$ of the dairy cattle in Aydin's registry system, are kept in a roofed-open, loose/free stall housing system (Table 6).

When it comes to housing, one of the most important topics is the bedding material. The $95 \%$ of farms that answered the question declared that there was no special bedding material in the barn. Only $4 \%$ of these farms use sand, while $1 \%$ of them use either hay or straw.

Having clean drinking water available for the adult and young cattle in the barn or in the pasture is another very important topic. The results of this survey show that
$95 \%$ of the dairy cattle in the barns have unlimited access to drinking water, while this ratio falls to $73 \%$ when they are at pasture. The main source of drinking water in the farms is city's water supply system $(\sim 60 \%)$. In some of the farms, there is an automated drinking bowl (11\%); however, $82 \%$ of all farms mostly use a watering trough.

Milking management: The survey shows that $97 \%$ of the cattle breeders use milking machine, while only $3 \%$ still milk the animals manually. Most of the milking machines used are portable/mobile (87\%) machines, generally preferred by small and medium sized farms (88.4\% in farms with 3-19 head cows). At the same time, $62 \%$ of all the milking parlors (fixed/immobile) are found in herds bigger than 20 cows.

In this study, $90 \%$ of the breeders declared that they call the technician or specialist twice a year or even more often, as recommended. Another important machinery on dairy farms is the cooling tank, which is found in $9 \%$ of the surveyed farms.

Calf care: It would not be wrong to comment that breeders in Aydin are aware of the importance of colostrum intake since $78 \%$ of them are feeding the calves with colostrum from bottle and a total of 4-5 days in average. Nonetheless, $14 \%$ of the surveyed farms continue feeding the calves with colostrum only 1 or 2 more days after birth. The breeders in Aydin mostly use a bottle fitted with a rubber teat to feed the calves with milk (80\%). On one hand, $88 \%$ of the milk fed is given to the calves without any heating process and just after milking, on the other hand a considerable amount of breeders prefer heating the milk before feeding (10\%). In Aydin, the calves are given water as early as possible, when they are 1 day old (in 50\% of the farms). The rest of the $31 \%$ of the farms start in the first week whereas in $19 \%$ calves start drinking water after the first week. When it comes to feeding roughage the average age changes between 3-4 weeks although calves are fed earlier with concentrate feed, at 2-3 weeks age. The weaning takes place at the age of nearly 3 months in Aydın, which means that milk feeding usually takes a little bit longer than recommended (Table 7). 
Table 7. Weaning age of female calves (days)

Tablo 7. Dişi buzağıların sütten kesilme yaşı (gün)

\begin{tabular}{lc}
\hline Weaning age of female calves (days) & Share of farms, $\%$ \\
\hline$=<30$ days & $1.0 \%$ \\
$30-59$ days & $19.9 \%$ \\
$60-89$ days & $64.1 \%$ \\
$90-120$ days & $11.2 \%$ \\
$>120$ days & $3.8 \%$ \\
Total, $\%$ & $100 \%$ \\
Total, Number of farms & 498 \\
Average age of weaning (days) & Mean \\
& Median \\
\hline
\end{tabular}

Despite the fact that preferably young calves should be individually housed for about 3 weeks, $30.6 \%$ of the surveyed farms declared that they keep the calves in a group pen while $64.9 \%$ keeps the calves in the same barn as the adult cattle. Only $4.5 \%$ of the farms are able to provide individual pens to its calves.

Herd health management: The frequency of veterinarian visits in the surveyed farms shows that most of the farms do not have planned, scheduled veterinary services, but rather the veterinarian visits the farm on call (39\%). Veterinarians are called each week in $23 \%$ of the farms which are between 3-49 heads while relatively higher herds receive such services more frequently $(30 \%$ of farms with 50-99 heads receive twice a week, $43 \%$ of herds which have more than 100 heads receive every day). The three main reasons for calling a veterinarian in the surveyed farms was found to be artificial insemination (46\%), treatment $(33 \%)$ and calving difficulty $(8 \%)$. As a result, it could be said that even in one of the most developed milk production regions in Turkey, veterinary services are not considered as a part of the herd health management and planning program. This becomes clear with $80 \%$ of the farms declaring that they do not have a vaccination program for their herd. Another reason for not having a herd level vaccination program could be the vaccination program currently being carried out by the Ministry of Food, Agriculture and Livestock for certain diseases.

The result of this survey is an important proof that most of the time breeders do not realize that their cows have mastitis. According to the survey results, $62 \%$ of the herds in Aydin do not have mastitis, only $38 \%$ of the breeders declared that there was mastitis in their herd with an average of 3 head cows per year. Linked with this question, the breeders were also asked whether they knew the bacteria count in their milk or not. The bacteria count of the milk is not known by $98 \%$ of the breeders.

Forage production and feed supply: Aydin region has a relatively high level of forage production since $91 \%$ of all surveyed farms declared producing at least one of the main forage crops of the region (Table 8).

With such a high rate of forage production, it is quite natural that the farm manure is mainly used as fertilizer in the agricultural land. Of all the farms surveyed (501 farms), 96\% uses the farm manure in own land for production while only $2 \%$ sell it and $0.6 \%$ uses it for heating.

Regarding buying of feeding material, 321 farms have declared buying roughage, 493 have declared buying concentrate for the feeding of dairy cows. Hay is one of the most commonly used roughage in dairy cattle farming in Aydin (94\% of 321), followed by fresh alfalfa and maize silage (22\%). Furthermore, 106 farms also use feed additives, namely mineral salt block (70\%), vitamins (27\%) and live yeast (10\%). Contrarily 19 farms do not think that the use of additives make a difference.

Feeding management: In order to understand the feeding management basics of the surveyed farms, the breeders were asked about their feeding practices during dry period of dairy cows. Nearly half of the breeders decrease the amount of roughage and concentrate feed when the cows are in dry period. However, there are still a significant number of breeders ( 89 breeders) who do not change the amount of feed given during dry and milking periods of lactation and who increase the amount of roughage while increasing concentrate feed (51 breeders). The farms, which change feeding according to the milking period, have increased 2.5 times since 2005 , from $32 \%$ (21) to $80 \%$ in 2011 . The survey results show that dairy cattle farms in Aydin feed their cows twice a day $(99 \%)$ (Table 9).

Table 8 . Number and share of farms producing main forage crops and average land size

Tablo 8. Başlıca yem bitkileri üreten işletme sayıları ve payları

\begin{tabular}{lccc}
\hline Forage production & Total number of farms & Share in total farms (\%) & Average land (da) \\
\hline Maize silage (dry+irr) & 338 & $74 \%$ & 29 \\
Vetch (dry+irr) & 250 & $55 \%$ & 33 \\
Wheat and Barley & 187 & $41 \%$ & 32 \\
Alfalfa (dry+irr) & 153 & $34 \%$ & 17 \\
Rutabaga & 52 & $11 \%$ & 8 \\
Other total (dry+irr) & 41 & $9 \%$ & 22 \\
Ryegrass & 8 & $2 \%$ & 12 \\
Total forage production & 456 & $100 \%$ & 56 \\
\hline
\end{tabular}


Table 9 . Feeding practices applied by surveyed breeders during dry period of dairy cows Tablo 9. Anket uygulanan yetiştiricilerin kuru dönemdeki besleme uygulamaları

\begin{tabular}{|c|c|c|c|c|}
\hline \multirow{2}{*}{ Roughage feeding in dry cows } & \multicolumn{4}{|c|}{ Concentrate feed use in dry cows } \\
\hline & No change & Increases & Decreases & Total \\
\hline No change & $17.8 \%$ & $0.4 \%$ & $19.0 \%$ & $37.2 \%$ \\
\hline Increases & $0.8 \%$ & $0.6 \%$ & $10.2 \%$ & $11.6 \%$ \\
\hline Decreases & $1.0 \%$ & $1.0 \%$ & $49.2 \%$ & $51.2 \%$ \\
\hline Total, $\%$ & $19.6 \%$ & $2.0 \%$ & $78.4 \%$ & $100 \%$ \\
\hline Total number of breeders & \multicolumn{4}{|c|}{500} \\
\hline
\end{tabular}

Another important factor in feeding management is the decision of balances of rations for the cows. The survey results show that $95 \%$ of the respondents decide by their own on how the daily ration should be.

Genetic improvement activities: If the role of breeders in genetic improvement is to be assessed for Aydin region, the results show that more than half of the breeders do not consider that the cows in the farm have any characteristics or traits that are inadequate or not improved sufficiently. In spite of this response, the other half $(45 \%)$ is aware of the inadequacies in the herd such as repeat breeding $(22 \%)$, low milk yield (14\%) and small body size $(3 \%)$.

Sire selection is equally important for animal breeding programs. Technicians have the biggest influence not only on the sire selection itself $(73 \%)$ but also on the selection of the sire origin (imported or local sire) $(60 \%)$, while the sire catalogues are in the second place $(19 \%)$. The influence of semen companies for selection of appropriate sire at the farm level is as low as $1 \%$. However, the origin of the AI bull, in other words, whether the semen is imported or obtained from local production, is a decision that $41 \%$ of the breeders prefer to make themselves. Imported frozen, tested bull semen is preferred (37\%) more than the local production (4\%).

Success of the farm: Breeders who participated in the survey were asked in which cases they would consider their farms successful, and the answers given to this open-ended question were grouped. The fact that $37 \%$ of the breeders consider the increase in milk prices as a success criterion, which suggests that their success depends on the milk prices rather than proper farm or herd management and planning, could only be related to the widespread quality based pricing system in this region. Increasing the milk yield and production is regarded as a success criterion by $22 \%$ of the breeders. The main point to be noted here is the low percentage of farmers who consider themselves successful with good herd management, healthy herd and improvement activities $(3.3 \%, 1.9 \%$, and $0.8 \%)$.

\section{Discussion and Conclusion}

Having a relatively younger breeder population (57.5\%), Aydın has a higher level of education (high school or higher) in the Herdbook System (14\%) when compared to the Pre-Herdbook System (5.5\%) and dairy cattle breeders of Burdur (15); but it has a lower level of education when compared to cattle breeders of Kars (26). However, it should be noted that research carried out in Burdur has a rate of only $45 \%$ and Kars has $73 \%$ CBA members in total surveyed farms

Cattle Breeders' Association of Aydin (CBAA) has increased the number of farms registered to its Herdbook database 2.6 times since 2005 and the herd size also increased significantly. Nizam (21) reported that $70 \%$ of Aydın CBA farms had a total of 5-10 heads in 2005 whereas majority (44\%) of the Herdbook farms had a herd size between 10-19 heads of cattle in 2011. It was also indicated that the share of farms making their own maize silage was $87 \%$ in 2005 in Aydin (21). This study has also showed that maize production for silage covers $35 \%$, vetch covers $29 \%$ and main cereals like wheat and barley covers $21 \%$ of the total land used for forage production in the surveyed farms.

Apart from the changes in Aydin over time, when compared with similar and recent survey study results, it could be seen that Aydın has parallel labor structure with that of Burdur and Kars. It is seen that more than half of the farms in Aydin have two or more family members working for the milk production and cattle breeding. Similarly, dairy cattle farms of Burdur show that in $99.5 \%$ of all farms the main labor used in the farm is family labor (15).

Another comparison could be made on housing and milking management practices. Holdings in Kars and Burdur have more enclosed housing systems, whether tied or free, when compared with the dairy cattle barns in Aydin. It could be seen that the share of enclosed housing systems are 5.6 times higher in Kars and 4.2 times higher in Burdur $(15,26)$. There is also a very significant difference in milking method with Kars, where Tilki et al. (26) have indicated that $81 \%$ of surveyed farms still milk by hand where as $97 \%$ of all surveyed farms have milking machines in Aydin. The milking machines must always be kept in perfect working order, should be periodically cleaned and get routine maintenance at least twice every year (11). 
Calf management is another important herd management practice related directly with future generations of the herd. While $64.9 \%$ of the breeders still keep the calves in the same barn as the adult cattle in Aydın, this share is even higher in Burdur (72\%) according to the results of the survey study carried out by Elmaz et al. (15). Access to information is not usually very easy for the breeders. Even thought the public support to the advisory services of farmer organizations, good quality consultancy services still remain a big problem, in particular for feeding and sire selection. Supporting this general observation, consulting to an expert for the preparation of daily feeding rations and feed balances is only an option for $4.3 \%$ of the respondents in Aydin. Similar data has been collected in Burdur with $93 \%$ self-decision of feeding (15).

The cow's health is very much linked to a healthy use of its feet and legs (13). In $78 \%$ of the surveyed farms, breeders stated that there were no feet and leg problems in their herds.

The presence of CBAA, which has a widespread service network and trained technical personnel, and of an Agricultural Development Cooperative named ÖrKoop, which has a deep-rooted history, have contributed greatly to the attainment of a high level of knowledge and awareness by breeders engaged in dairy cattle breeding in Aydin. On the other hand, survey results indicate that farms still need to enhance their knowledge in particular in feeding, calf care, housing and herd health management while also improving their managerial skills.

Above all, they should be more aware of the genetic improvement activities and practices going on in their own farms. Record keeping, particularly keeping track of accounting could increase the productivity and profitability of the farm since it is the main tool for identifying the current problems.

\section{Acknowledgements}

This study was supported by EU funded Project "Building Knowledge Bridges on Dairy Farm Management for Future" (TR0703.01-02/178) and Cattle Breeders' Association of Aydin.

\section{References}

1. Açll AF, Demirci R (1984): Tarım Ekonomisi Dersleri. A.Ü. Ziraat Fakültesi Yayınları No: 880, Ankara.

2. Anonim (2012a): Hayvansal üretim ve nüfus istatistikleri. Erişim: www.tuik.gov.tr, Erişim Tarihi: 09.08.2012.

3. Anonim (2012b): Soykütüğ̈̈ istatistikleri. Türkiye Damızlık Sığır Yetiştiricileri Merkez Birliği, Ankara.

4. Anonymous (2012a): FAO Agricultural Statistics. Website: http://faostat.fao.org, Cited: 05.08.2012.

5. Anonymous (2012b): EUROSTAT, Population Statistics. Website:

http://epp.eurostat.ec.europa.eu/portal/page/portal/statistics /search_database, Cited: 24.09.2012.
6. Anonymous (2012c): Agriculture in the European Union, Statistical and Economic Information. Website: http://ec.europa.eu/agriculture/statistics/agricultural/ 2011/index_en.htm, Cited: 24.09.2012.

7. Anonymous (2012d): International Programs. Website: http://www.census.gov/

population/international/data/idb/informationGateway.php, Cited: 04.08.2012.

8. Anonymous (2012e): United States Department of Agriculture National Agricultural Statistics. Website: http://www.nass.usda.gov/Service, Cited: 24.09.2012.

9. Anonymous (2012f): Veepro NL Dairy herd administration management. Website: http://www.veepro.nl/uploadimages/VeeproDairyHerdAd minManagementsmall.pdf, Cited: 25.09.2012.

10. Anonymous (2012g): Canada plan service dairy cattle housing and equipment. Website:

http://www.cps.gov.on.ca/english/frameindex.htm, Cited: 20.01.2012.

11. Anonymous (2012h): Veepro NL Proper milking management. Website:

http://www.veepro.nl/uploadimages/VeeproProperMilking Managementsmall.pdf, Cited: 20.01.2012.

12. Anonymous (2012i): Veepro NL Young stock management. Website:

http://www.veepro.nl/uploadimages/VeeproYoungStockM anagementsmall.pdf, Cited: 22.01.2012.

13. Anonymous (2012j): Veepro NL Foot care management. Website:

http://www.veepro.nl/uploadimages/VeeproFoodCareMan agementsmall.pdf, Cited: 26.01.2012.

14. Cabrera VE, Solis D, del Corral J (2010): Determinants of technical efficiency among dairy farms in Wisconsin. $\mathrm{J}$ Dairy Sci, 93(1), 387-393.

15. Elmaz Ö, Saatcı M, Özçelik MM, Sipahi C (2010): Burdur ili süt sı̆̆ırcılığı ve özellikleri. Proje sonuç raporu, Mehmet Akif Ersoy Üniversitesi Veteriner Fakültesi, Burdur.

16. Grant RJ, Albright JL (1995): Feeding behavior and management factors during the transition period in dairy cattle. J Anim Sci, 73(9), 2791-2803.

17. İşcan U, Özder M, Önal AR (2010): Tekirdağ Damızlık Siğır Yetiştiricileri Birliği’ne üye işletmelerin gelişim süreci ve bugünkü durumu. Tekirdağ Ziraat Fakültesi Dergisi, 7(2), 131-137.

18. Jonker JS, Kohn RA, High J (2002): Dairy herd management practices that impact nitrogen utilization efficiency. J Dairy Sci, 85(5), 1218-1226.

19. Kaygısız A, Tümer R, Orhan H, Vanlı Y (2008): Kahramanmaraş bölgesi süt sığır işletmelerinin yapısal özellikleri: I. Yetisstirme uygulamaları. Süleyman Demirel Üniversitesi Ziraat Fakültesi Dergisi, 3(2), 23-31.

20. Keown JF, Kononoff PJ, Larson LL (2012): Dairy health management for optimum production and reproductive performance. Website:

http://www.ianrpubs.unl.edu/live/g1285/build/g1285.pdf, Cited: 25.09 .2012$.

21. Nizam S (2006): Aydın ilinde pazara yönelik süt sığırcılı̆̆ işletmelerinin verimliliklerinin belirlenmesi. Aydın Damızlık Sığır Yetiştiricileri Birliği Yayınları No:2007-1, Aydın. 
22. Önal AR, Özder M (2008): Edirne ili Damızlık Siğır Yetiştiricileri Birliğine üye işletmelerin yapısal özellikleri. Tekirdağ Ziraat Fakültesi Dergisi, 5(2), 197-203.

23. Savran F (2003): Çanakkale Damızlık Süt Sığııı Yetişstirici Birliğine Üye olan ve olmayan işletmelerin kullandiklar üretim teknikleri ve sosyal karakteristiklerin karşılaştırılması. Tarım Bilimleri Dergisi, 9(4), 450-453.

24. Soyak A, Soysal MI, Gürcan EK (2007): Tekirdă̆ ili süt siğırcılı̆̆ işletmelerinin yapısal özellikleri ve bu işletmelerdeki siyah alaca süt sı̆̆ırlarının çeşitli morfolojik özellikleri üzerine bir araştırma. Tekirdağ Ziraat Fakültesi Dergisi, 4(3), 297-305.

25. Stahl TJ, Conlin BJ, Seykora AJ, Steuernagel GR (1999): Characteristics of Minnesota dairy farms that significantly increased milk production from 1989-1993. J Dairy Sci, 82(1), 45-51.
26. Tilki M, Sarı M, Aydın E, Işık S, Aksoy AR (2012): Kars ili slğır işletmelerinde barınakların mevcut durumu ve yetiştirici talepleri: I. Mevcut durum. Kafkas Univ Vet Fak Derg. (Baskıda).

Geliş tarihi: 09.10.2012 / Kabul tarihi: 23.10.2012

\section{Address for correspondence:}

Dr. Yılmaz Aral

Ankara University, Faculty of Veterinary Medicine Department of Animal Health Economics and Management 06110 Dışkapı, Ankara, Turkey.

e-mail: yaral@veterinary.ankara.edu.tr 